\title{
A newly designed intramedullary nail with distal interlocking system for tibia fractures in adults - the clinical results
}

\author{
Yetişkinlerdeki tibia kırıkları için yeni dizayn edilmiş bir intramedüller çivi ve \\ distal kilit sistemi, klinik sonuçlarımız
}

\author{
Fatih KÜÇÜKDURMAZ, ${ }^{1}$ Fuat AKPINAR, ${ }^{2}$ Gürsel SAKA, ${ }^{2}$ Necdet SAĞLAM, ${ }^{2}$ Cihan ACI ${ }^{2}$
}

\section{BACKGROUND}

The surgical treatment of fractures of the tibia includes reamed and unreamed options. Reamed nails have mechanical advantages but they significantly harm the endosteal circulation. Unreamed nails spare the endosteal circulation, but provide a less stable fixation. In both systems, immediate full weight-bearing is not possible due to instability related to distal interlocking (DI). Further, DI is responsible for the majority of the fluoroscopy requirement and a significant loss of surgical time. In our study, we present the clinical results of a new intramedullary (IM) nail and system, which allows stable fixation with an unreamed technique that permits immediate full weight-bearing, with a minimum fluoroscopy requirement for DI.

\section{METHODS}

Fifty tibia fractures (49 patients) operated using our new IM system between 2008 and 2010 were evaluated retrospectively. They were allowed full weight-bearing the day after surgery. The patients were followed at least 10 months postoperatively.

\section{RESULTS}

Mean fluoroscopy time was 18 seconds (min: 10, max: 30) for DI. Mean union time was 9 weeks (min: 6, max: 12). There was no neurovascular injury, deep infection, malunion, delayed union, or nonunion.

\section{CONCLUSION}

We demonstrated that our newly developed IM nail and new DI system may be an option to solve the stability problems sourced from the DI screw. It also significantly decreases the requirement of fluoroscopy.

Key Words: Distal interlocking; fluoroscopy; immediate full weight-bearing; stability; tibia fracture.

\section{AMAÇ}

Tibia kırıklarının cerrahi tedavisinde oymalı ve oymasız seçenekler vardır. Oymalı çivilerin biyomekanik üstünlükleri vardır ancak endosteal dolaşıma önemli ölçüde zarar verir. Oymasız çiviler ise endosteal dolaşımı korur fakat daha az stabil bir sabitleme sağlar. Her iki sistemde de distal kilit vidası kaynaklı instabilite nedeniyle hemen tam ağırlık vermek mümkün değildir. Ayrıca, distal kilit vidası, skopi kullanma ihtiyacının ve cerrahi sürenin uzamasından sorumludur. Bu çalışmada, yeni intramedüller çivi ve oymasız sistemle stabil bir sabitleme sağlayıp hemen tam ağılık vermeye izin veren distal kilit vidası sisteminin klinik sonuçları sunuldu.

\section{GEREÇ VE YÖNTEM}

2008 ile 2010 y1lları arasında yeni intramedüller sistemle ameliyat edilmiş 50 tibia kırığı (49 hasta) geriye dönük olarak değerlendirildi. Ameliyattan hemen sonraki 1. gün tam ağırlığa izin verildi. Hastalar ameliyat sonrası en az 10 ay takip edildi.

\section{BULGULAR}

Distal kilitleme için ortalama skopi süresi 18 saniye (min: 10, maks: 30) idi. Ortalama kaynama süresi 9 hafta (min: 6 , maks: 12). Nörovasküler yaralanma, derin enfeksiyon, yanlış veya gecikmiş kaynama ve kaynamama yoktu.

SONUÇ

Biz bu çalışmamızla yeni geliştirdiğimiz intramedüller çivinin ve distal kilit vidası sisteminin distal kilit vidasından kaynaklanan stabilite problemlerinin çözülmesinde bir seçenek olabileceğini gösterdik. Ayrıca sistemimiz ameliyatta gereken skopi ihtiyacını da önemli ölçüde azaltmaktadır.

Anahtar Sözcükler: Distal kilit vidası; skopi; hemen tam ağırlık verme; stabilite; tibia kırı̆̆g.

\footnotetext{
${ }^{1}$ Department of Orthopedics and Traumatology, Bezmialem Vakıf University, Istanbul; ${ }^{2}$ Department of Orthopedics and Traumatology, Umraniye Training and Research Hospital, Istanbul, Turkey.
}

${ }^{1}$ Bezmialem Vakıf Üniversitesi, Ortopedi ve Travmatoloji Anabilim Dall, İstanbul; Ümraniye Eğitim ve Araştırma Hastanesi, Ortopedi ve Travmatoloji Kliniği, İstanbul. 
Intramedullary (IM) nailing has been the gold standard treatment for tibia fractures. ${ }^{[1-3]}$ However, there is a debate on the superiority of reamed versus unreamed IM nailing systems. IM nailing with reaming has mechanical advantages with its larger possible diameters and larger surface-area contact between the bone and nail. ${ }^{[4,5]}$ On the other hand, reaming of the medulla significantly increases the IM pressure and heat. ${ }^{[6]}$ Unreamed nails are smaller in diameter and preserve the endosteal blood supply, which allows more biological fixation with a cost of less stable fixation. ${ }^{[7]}$ Consequently, the biological advantages of unreamed tibial nailing are associated with specific disadvantages. In case of limited nail-bone contact as when unreamed nails are used, the interlocking screw-nail interface becomes an important contributor to the construct stability ${ }^{[8]}$ Disparity between the distal interlocking (DI) screw hole and nail would inevitably reduce the stability and cause increased interfragmentary movements. ${ }^{[9]}$ This stress to the screws can also cause screw loosening or screw failure. ${ }^{[10]}$ In addition to these mechanical problems, DI is also responsible for the majority of radiation exposure and a significant investment of surgical time in the entire procedure. ${ }^{[11,12]}$ In order to overcome the problems regarding DI, various techniques and devices have been developed. ${ }^{[13-}$ ${ }^{19]}$ Despite their developments, no system has gained common acceptance and popularity; thus, DI remains a problem.

In this study, we present the clinical results of a newly developed unreamed IM nail with a new DI system, the Distal Bolt Locking Screw (DSBLS), which allows full weight- bearing (FWB) the day after surgery. It also allows easy DI, which requires significantly less fluoroscopy.

\section{MATERIALS AND METHODS}

\section{Patients}

The results of 50 surgically treated tibia fractures in 49 adult patients between May 2008 and May 2010 were evaluated retrospectively. There were 4 isolated tibia and 46 lower leg fractures. Twenty-two of the fractures were shaft and 28 were distal tibia fractures (Table 1). The mean age was 39 (min: 17, max: 80). One patient had bilateral tibia fractures, with a tibia shaft and tibia plateau fracture on one side and distal tibia fracture on the other side. One patient had Gustilo-Andersen type 1 open fracture. One patient had an acetabulum fracture on the same side as the distal tibia fracture.

\section{Intramedullary Nail Set}

The IM nails may be used either reamed or unreamed. The nail is available in diameters from 7 to $12 \mathrm{~mm}$ and in lengths from 280 to $400 \mathrm{~mm}$. The DSBLS was cannulated for a set screw (Fig. 1) and was
Table 1. Fracture types according to the AO classification system

\begin{tabular}{|c|c|c|c|}
\hline \multicolumn{3}{|c|}{ Type of fracture } & \multirow{2}{*}{$\frac{\text { Number of patients }}{6}$} \\
\hline \multirow[t]{9}{*}{42} & A & 1 & \\
\hline & & 2 & 2 \\
\hline & & 3 & 3 \\
\hline & $\mathrm{B}$ & 1 & 2 \\
\hline & & 2 & 3 \\
\hline & & 3 & 3 \\
\hline & C & 1 & - \\
\hline & & 2 & 2 \\
\hline & & 3 & 1 \\
\hline \multirow[t]{3}{*}{43} & A & 1 & 12 \\
\hline & & 2 & 6 \\
\hline & & 3 & 8 \\
\hline Total & & & 48 \\
\hline
\end{tabular}

standard in diameter, $8 \mathrm{~mm}$, but had different lengths, ranging from $34-42 \mathrm{~mm}$.

The distal end of the IM nail was designed to be engaged to the DSBLS (Fig. 2). The DSBLS was positioned to leave the larger end of the funnel-like hole

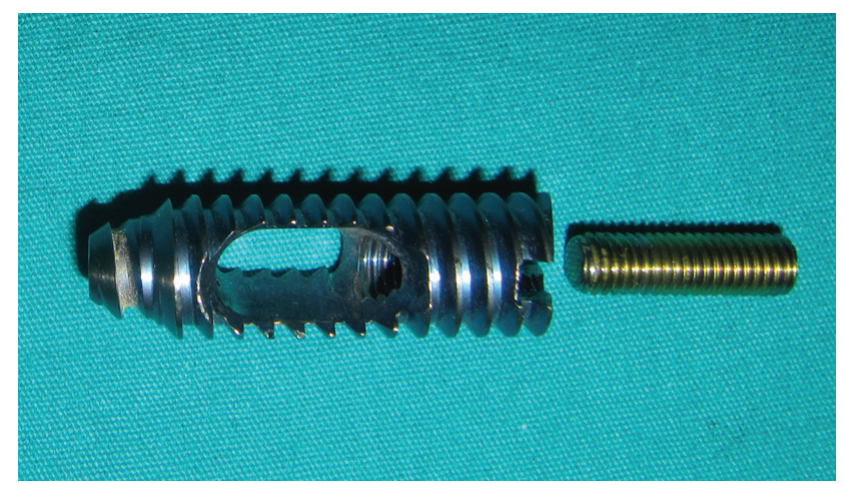

Fig. 1. The DSBLS, set screw and the hole for the set screw are seen.

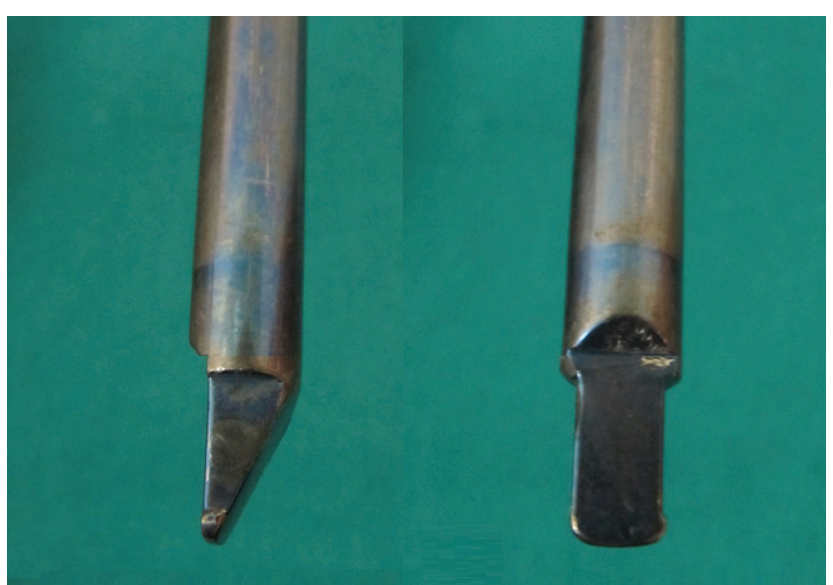

Fig. 2. The distal end of the intramedullary nail has a special design that makes engagement to the DSBLS possible. (Color figures can be viewed in the online issue, which is available at www.tjtes.org). 


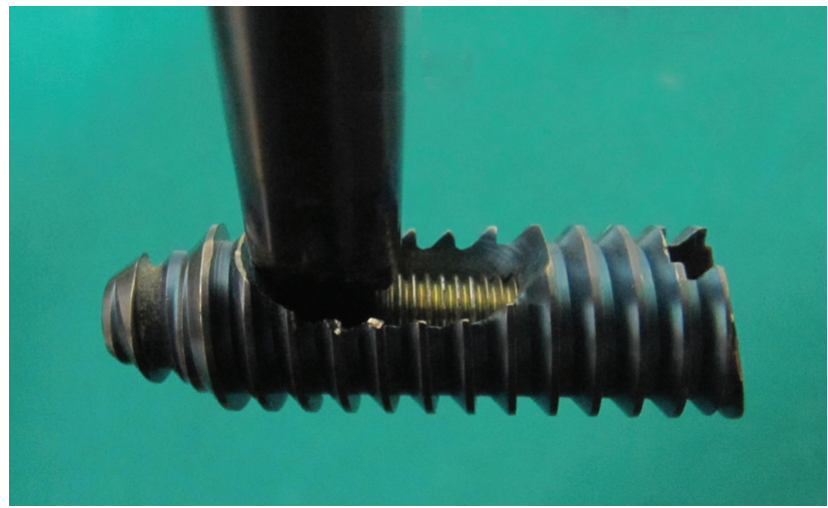

Fig. 3. The design allows rigid fixation of the nail within the DSBLS with a set screw after the engagement.

(Color figures can be viewed in the online issue, which is available at www.tjtes.org).

facing in the superior direction, which is indicated by a mark on the DSBLS. The design allows rigid fixation of the nail within the DSBLS with a set screw after the engagement (Fig. 3).

\section{Operation}

The operations were performed by 10 surgeons. A standard point of application for the DSBLS was determined as at the intersection point of approximately $3 \mathrm{~cm}$ proximal to the distal tip of the medial malleolus and the middle of the tibia in the sagittal plane. Then, the DSBLS was inserted from the medial to lateral aspect in the distal tibia in a predrilled channel. This step was followed by inserting the selected unreamed nail from the standard point of insertion in the proximal tibia. The insertion of the nail through the medulla was advanced until the engagement of the nail with the DSBLS. The success of the engagement may be confirmed with fluoroscopy (Fig. 4). The nail does not have to approach the DI screw precisely (Figs. 4, 5). Another method of confirmation without using fluo-

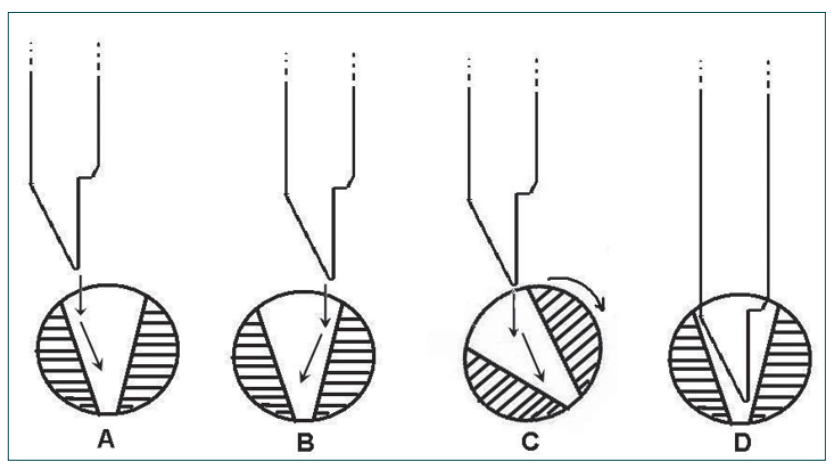

Fig. 5. The nail and distal interlocking screw (DSBLS) is drawn from the lateral aspect. The guiding effect is seen even if the nail drops anteriorly (A) or posteriorly (B) within a certain range. If the nail drops more anteriorly $(\mathrm{C})$, the DSBLS is turned anteriorly and the nail is thusly caught by the DSBLS, and it returns to normal position by moving the nail further (D).

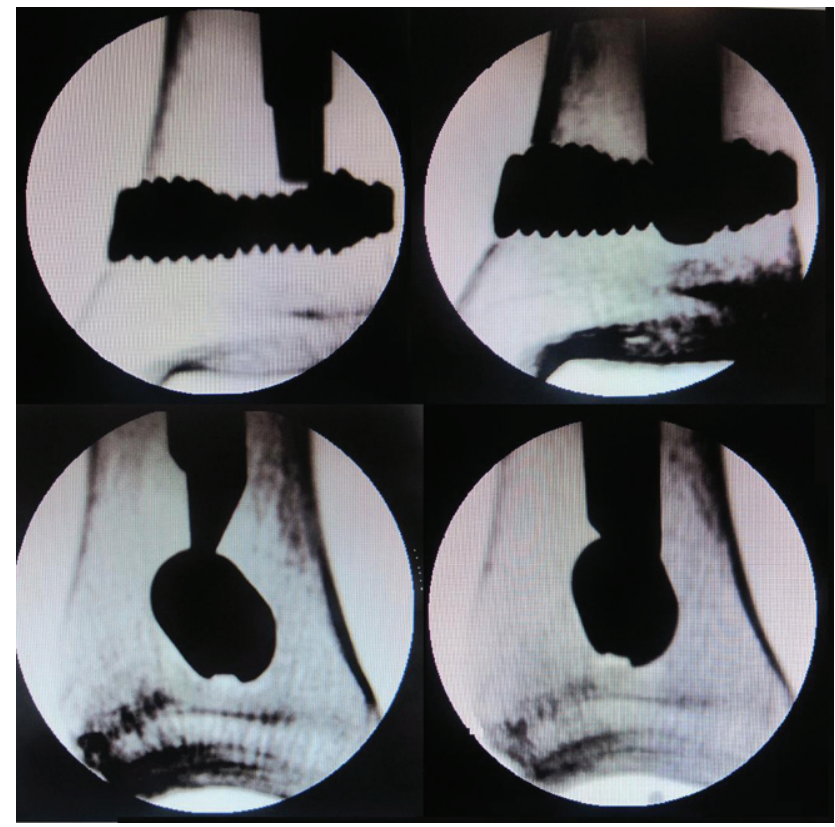

Fig. 4. The progress (A) and success (B) of the engagement may be confirmed with fluoroscopy.

roscopy was made using a Kirschner wire. If the nail is successfully engaged, it is not possible to advance the wire more than $5 \mathrm{~mm}$ in the set screw hole (Fig. 6).
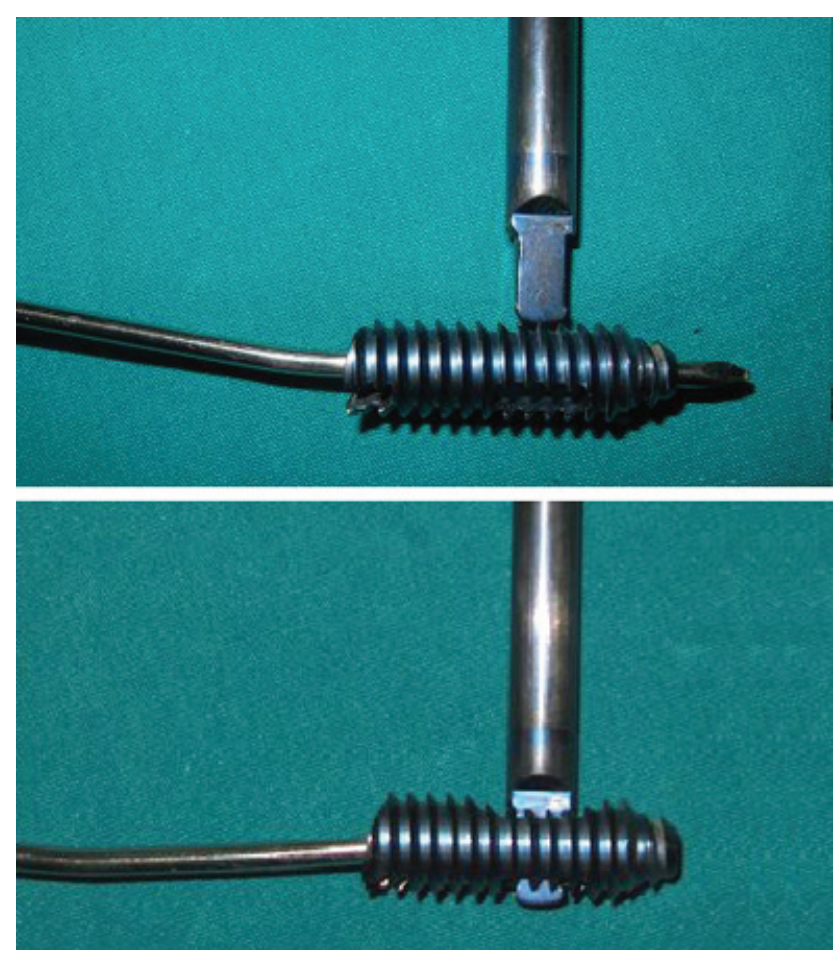

Fig. 6. Confirmation of the engagement with a Kirschner wire and without using fluoroscopy is seen. The nail is successfully engaged so it is not possible to advance the wire more than $5 \mathrm{~mm}$ in the set screw hole (A). If the engagement is not successful, however, the wire advances through the whole length of the set screw hole (B).

(Color figures can be viewed in the online issue, which is available at www.tjtes.org). 
The proximal interlocking was done with a proximal guide, as attached to the nail, and two screws were used in all patients.

Another method for DI was to insert the nail to a few centimeters above the localization of the DSBLS and then place the screw precisely below the tip of the nail, after which, the nail was inserted further into its final position.

\section{Follow-Up}

We took standard anteroposterior (AP) and lateral (Lat) views weekly for the first four weeks, and then at the 6th, 9th and 12th weeks. Radiological callus formation was recorded for each view, and union was assumed if there was callus in both views, without pain on palpation and weight-bearing at the fracture site. We recorded the fluoroscopy time for DI. For all patients, FWB was allowed immediately postoperatively and range of motion the day after surgery without any type of external support except for the one patient who had an acetabular fracture.

\section{RESULTS}

Mean fluoroscopy time was 18 seconds (min: 10, max: 30) for DI. The patients were followed for at least 10 months (min: 10 months, max: 3 years). The mean radiological union time was 9 weeks (min: 6, max: 12). There were no malunion, delayed union or nonunion. During weight-bearing, none of the patients expressed pain interference with their daily activities. None of the patients had complications of deep infection, regional dystrophic syndrome or neurovascular injury.

\section{DISCUSSION}

Intramedullary (IM) nailing of fractures of the tibia is the most commonly accepted surgical treatment in adults. Despite the advantages of IM nailing, immediate FWB is not possible, especially if the fracture extends distally or proximally and when unreamed IM nailing is performed using the currently available systems. The interfragmentary movements at the fracture site are found to be increased when unreamed nailing is performed. ${ }^{[20]}$ When interfragmentary movement is increased, complications like nonunions, delayed unions or malunions are significantly increased.

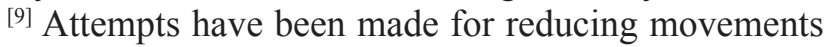
and increasing stability at the fracture site following IM nailing. ${ }^{[21]}$ Nevertheless, none of the currently available unreamed nailing systems provides enough stability to allow FWB the day after surgery. In our IM nail system, all patients are allowed FWB the day after surgery and none of them experienced a complication that could be related to instability of the fracture site.

It is clearly demonstrated that limited axial interfragmentary movement provides an effective stimulus for periosteal callus formation and thereby accelerates healing. ${ }^{[21-23]}$ On the other hand, the shearing forces affecting the fracture site are detrimental to fracture repair. Thus, the newly developed systems are targeting angular stability by modifying DI options ${ }^{[10,21,24,25]}$ and early weight-bearing. ${ }^{[26,27]}$ The rationale for this is, if the nail is an angular stable construct, weight-bearing acts as cyclic axial loading on the fracture site, which enhances periosteal callus formation. However, in these circumstances, the IM nails act as load-sharing devices and transmit vertical forces on the transverse interlocking screws until the bony union, especially if unreamed nailing is performed. This fatigue stress to screws may cause failure or produce metal splinters on their surface. ${ }^{[8,25,28]}$

In our series, we used our newly designed unreamed IM nail and allowed FWB the day after surgery. We had no implant failure even in unstable and distal tibia fractures. To our knowledge, in the current
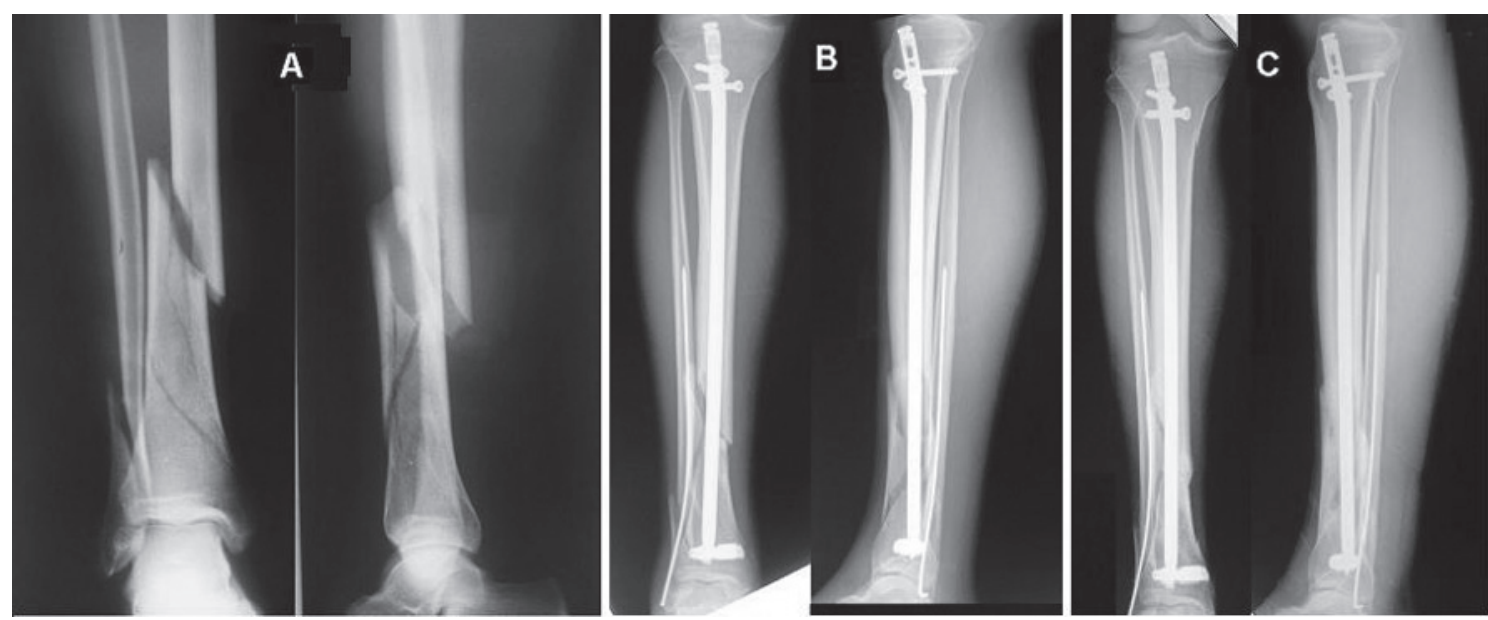

Fig. 7. The preoperative (A), postoperative 1st day (B) and postoperative 6th month (C) follow-up X-rays of a segmental tibia fracture are seen. 
English literature, there is no series allowing immediate FWB following unreamed IM nailing of the tibia.

Unreamed nails are biologically more advantageous, because they partially preserve the endosteal blood supply and spare the cortical blood supply. ${ }^{[29-31]}$ The IM pressure and heat generated by the insertion of a tibial nail without reaming are significantly smaller than those resulting from reamed tibial nailing. ${ }^{[32-36]}$ These advantages contribute to a favorable bone healing. On the other hand, when unreamed nails are used, nail-bone contact decreases, which causes mechanical insufficiency, and as a result, the interfragmentary movement is more apparent. ${ }^{[20,21]}$ The literature confirms higher nonunion rates with unreamed IM nails in the clinical setting. ${ }^{[37]}$ Although we used unreamed IM nails in this study, no nonunion or delayed union was seen even in the distal and unstable fractures (Fig. 7). Our IM nail system has the biological advantages of unreamed systems, while at the same time providing superior stability features according to currently available reamed IM nail systems.

The DI step usually lengthens the operation time and causes prolonged radiation exposure of the surgical team. ${ }^{[38,39]}$ The importance of minimizing ionizing radiation during the surgery is well-known, ${ }^{[40,41]}$ and this risk has been the impetus for many clinicians to develop surgical techniques and/or recommendations that would limit the need for fluoroscopy. ${ }^{[42]}$ The devices developed for reducing fluoroscopy time in DI are either nail or image-intensifier mounted targeting device ${ }^{[43,44]}$ as well as computer-based navigation systems. ${ }^{[45-47]}$ Image-intensifier mounted systems do not allow micro movements ${ }^{[38]}$ and may be difficult to adapt to all image intensifiers. The nail-mounted systems have some disadvantages that make them unpopular: The weight of these devices declines their distal ends slightly towards the floor when used in the supine position, ${ }^{[47]}$ and deformation of the nail secondary to insertion-related bending ${ }^{[48]}$ and displacement due to the force applied to the device during the drilling have been observed. Computer-based systems are complex, expensive and not radiation-free. Setting up these systems is also time-consuming. ${ }^{[49,50]}$

The results of this study demonstrate that our newly designed IM nail system is superior to the currently available IM nail systems. Our system is completely different in its conception. In contrast to the currently available devices, the first step is to place the DI screw and then the nail is engaged to the screw, instead of using the DI screws at the last step of the procedure. The funnel-like canal in the DSBLS allows for easy engagement of the sharp end of the nail. This makes interlocking easier and dramatically decreases fluoroscopy time. In order to be able to perform a precise interlocking with our system, one has to make preopera- tive planning and determine the most suitable length of the nail. If the selected nail remains short, the nail may be extended with proximal end cups in different lengths within the set. If the nail remains long then the only option is to replace it with a suitable one.

Precise matching of the DSBLS and the distal end of the nail is not always necessary. Even if the nail mismatches in the sagittal or coronal plane (Fig. 4) at a certain range, moving the nail further or manipulation of the distal tibial fragment is enough to oppose the nail and the DSBLS hole. Because the DSBLS has a funnel-like hole with a wider upper end, it provides a guiding effect for the distal end of the nail (Fig. 5).

The operations were performed in one clinic by 10 different surgeons. Even with the range of surgeons, the outcome among patients was quite similar between surgeons. The learning curve regarding this new system is short.

In conclusion, although stability features should be supported by biomechanical studies, the rigid fixation of the nail with a DI screw, the DSBLS, provides superior stability properties in the clinical setting.

\section{REFERENCES}

1. Im GI, Tae SK. Distal metaphyseal fractures of tibia: a prospective randomized trial of closed reduction and intramedullary nail versus open reduction and plate and screws fixation. J Trauma 2005;59:1219-23.

2. Janssen KW, Biert J, van Kampen A. Treatment of distal tibial fractures: plate versus nail: a retrospective outcome analysis of matched pairs of patients. Int Orthop 2007;31:709-14.

3. Goldhahn S, Moser R, Bigler R, Matter P. Treatment methods and outcomes of tibial shaft fractures in Switzerland. A prospective multicenter study of the Swiss AO. Swiss Surg 2000;6:315-22. [Abstract]

4. Finkemeier CG, Schmidt AH, Kyle RF, Templeman DC, Varecka TF. A prospective, randomized study of intramedullary nails inserted with and without reaming for the treatment of open and closed fractures of the tibial shaft. J Orthop Trauma 2000;14:187-93.

5. Bonnevialle P, Bellumore Y, Foucras L, Hézard L, Mansat M. Tibial fracture with intact fibula treated by reamed nailing. Rev Chir Orthop Reparatrice Appar Mot 2000;86:29-37. [Abstract]

6. Heim D, Schlegel U, Perren SM. Intramedullary pressure in intramedullary nailing of the femur and tibia. Helv Chir Acta 1994;60:605-10.

7. Klein MP, Rahn BA, Frigg R, Kessler S, Perren SM. Reaming versus non-reaming in medullary nailing: interference with cortical circulation of the canine tibia. Arch Orthop Trauma Surg 1990;109:314-6.

8. Schüller M, Weninger P, Tschegg E, Jamek M, Redl H, Stanzl-Tschegg S. Micromotion at the fracture site after tibial nailing with four unreamed small-diameter nails--a biomechanical study using a distal tibia fracture model. J Trauma 2009;66:1391-7.

9. Horn J, Linke B, Höntzsch D, Gueorguiev B, Schwieger K. Angle stable interlocking screws improve construct stability of intramedullary nailing of distal tibia fractures: a biome- 
chanical study. Injury 2009;40:767-71.

10. Forster MC, Bruce AS, Aster AS. Should the tibia be reamed when nailing? Injury 2005;36:439-44.

11. Lee MY, Kuo CH, Hung SS. A new fluoroscopy-free navigation device for distal interlocking screw placement. J Med Eng Technol 2008;32:284-95.

12. Krettek C, Könemann B, Farouk O, Miclau T, Kromm A, Tscherne H. Experimental study of distal interlocking of a solid tibial nail: radiation-independent distal aiming device (DAD) versus freehand technique (FHT). J Orthop Trauma 1998;12:373-8.

13. Whatling GM, Nokes LD. Literature review of current techniques for the insertion of distal screws into intramedullary locking nails. Injury 2006;37:109-19.

14. Gugala Z, Nana A, Lindsey RW. Tibial intramedullary nail distal interlocking screw placement: comparison of the freehand versus distally-based targeting device techniques. Injury 2001;32:21-5.

15. Abdlslam KM, Bonnaire F. Experimental model for a new distal locking aiming device for solid intramedullary tibia nails. Injury 2003;34:363-6.

16. Madan S, Blakeway C. Radiation exposure to surgeon and patient in intramedullary nailing of the lower limb. Injury 2002;33:723-7.

17. Pardiwala D, Prabhu V, Dudhniwala G, Katre R. The AO distal locking aiming device: an evaluation of efficacy and learning curve. Injury 2001;32:713-8.

18. Riley SA. Exposure of the orthopaedic surgeon to radiation. J Bone Joint Surg Am 1994;76:952-3.

19. Levin PE, Schoen RW Jr, Browner BD. Radiation exposure to the surgeon during closed interlocking intramedullary nailing. J Bone Joint Surg Am 1987;69:761-6.

20. Augat P, Penzkofer R, Nolte A, Maier M, Panzer S, v Oldenburg G, et al. Interfragmentary movement in diaphyseal tibia fractures fixed with locked intramedullary nails. J Orthop Trauma 2008;22:30-6.

21.Penzkofer R, Maier M, Nolte A, von Oldenburg G, Püschel $\mathrm{K}$, Bühren $\mathrm{V}$, et al. Influence of intramedullary nail diameter and locking mode on the stability of tibial shaft fracture fixation. Arch Orthop Trauma Surg 2009;129:525-31.

22. Bhandari M, Tornetta P 3rd, Sprague S, Najibi S, Petrisor B, Griffith L, et al. Predictors of reoperation following operative management of fractures of the tibial shaft. J Orthop Trauma 2003;17:353-61.

23. Hou T, Li Q, Luo F, Xu J, Xie Z, Wu X, Zhu C. Controlled dynamization to enhance reconstruction capacity of tissueengineered bone in healing critically sized bone defects: an in vivo study in goats. Tissue Eng Part A 2010;16:201-12.

24. Wehner T, Penzkofer R, Augat P, Claes L, Simon U. Improvement of the shear fixation stability of intramedullary nailing. Clin Biomech (Bristol, Avon) 2011;26:147-51.

25. Gueorguiev B, Wähnert D, Albrecht D, Ockert B, Windolf M, Schwieger K. Effect on dynamic mechanical stability and interfragmentary movement of angle-stable locking of intramedullary nails in unstable distal tibia fractures: a biomechanical study. J Trauma 2011;70:358-65.

26. Hente R, Füchtmeier B, Schlegel U, Ernstberger A, Perren $\mathrm{SM}$. The influence of cyclic compression and distraction on the healing of experimental tibial fractures. J Orthop Res 2004;22:709-15.

27. Weaver AS, Su YP, Begun DL, Miller JD, Alford AI, Goldstein SA. The effects of axial displacement on fracture callus morphology and MSC homing depend on the timing of application. Bone 2010;47:41-8.
28. Kaspar K, Schell H, Seebeck P, Thompson MS, Schütz M, Haas NP, et al. Angle stable locking reduces interfragmentary movements and promotes healing after unreamed nailing. Study of a displaced osteotomy model in sheep tibiae. J Bone Joint Surg Am 2005;87:2028-37.

29. Hupel TM, Weinberg JA, Aksenov SA, Schemitsch EH. Effect of unreamed, limited reamed, and standard reamed intramedullary nailing on cortical bone porosity and new bone formation. J Orthop Trauma 2001;15:18-27.

30. Shepherd LE, Shean CJ, Gelalis ID, Lee J, Carter VS. Prospective randomized study of reamed versus unreamed femoral intramedullary nailing: an assessment of procedures. J Orthop Trauma 2001;15:28-33.

31. Ruchholtz S, Nast-Kolb D, Schweiberer L. Intramedullary nailing of lower leg fractures with minimal soft tissue injuries. Orthopade 1996;25:197-206. [Abstract]

32. Saldua NS, Kuhn KM, Mazurek MT. Thermal necrosis complicating reamed intramedullary nailing of a closed tibial diaphysis fracture: a case report. J Orthop Trauma 2008;22:737-41.

33. Leunig M, Hertel R. Thermal necrosis after tibial reaming for intramedullary nail fixation. A report of three cases. J Bone Joint Surg Br 1996;78:584-7.

34. Mawhinney IN, Maginn P, McCoy GF. Tibial compartment syndromes after tibial nailing. J Orthop Trauma 1994;8:2124.

35. Karunakar MA, Frankenburg EP, Le TT, Hall J. The thermal effects of intramedullary reaming. J Orthop Trauma 2004; 18:674-9.

36. García OG, Mombiela FL, De La Fuente CJ, Aránguez MG, Escribano DV, Martín JV. The influence of the size and condition of the reamers on bone temperature during intramedullary reaming. J Bone Joint Surg Am 2004;86-A:994-9.

37. Larsen LB, Madsen JE, Høiness PR, Øvre S. Should insertion of intramedullary nails for tibial fractures be with or without reaming? A prospective, randomized study with 3.8 years' follow-up. J Orthop Trauma 2004;18:144-9.

38. Whatling GM, Nokes LD. Literature review of current techniques for the insertion of distal screws into intramedullary locking nails. Injury 2006;37:109-19.

39. Fan CY, Chiang CC, Chuang TY, Chiu FY, Chen TH. Interlocking nails for displaced metaphyseal fractures of the distal tibia. Injury 2005;36:669-74.

40. Barry TP. Radiation exposure to an orthopedic surgeon. Clin Orthop Relat Res 1984;182:160-4.

41. Sugarman ID, Adam I, Bunker TD. Radiation dosage during AO locking femoral nailing. Injury 1988;19:336-8.

42. Babis GC, Benetos IS, Zoubos AB, Soucacos PN. The effectiveness of the external distal aiming device in intramedullary fixation of tibial shaft fractures. Arch Orthop Trauma Surg 2007; 127:905-8.

43. Gugala Z, Nana A, Lindsey RW. Tibial intramedullary nail distal interlocking screw placement: comparison of the freehand versus distally-based targeting device techniques. Injury $2001 ; 32: 21-5$.

44. Tyropoulos S, Garnavos C. A new distal targeting device for closed interlocking nailing. Injury 2001;32:732-5.

45. Slomczykowski MA, Hofstetter R, Sati M, Krettek C, Nolte LP. Novel computer-assisted fluoroscopy system for intraoperative guidance: feasibility study for distal locking of femoral nails. J Orthop Trauma 2001;15:122-31.

46. Hofstetter R, Slomczykowski M, Sati M, Nolte LP. Fluoroscopy as an imaging means for computer-assisted surgical navigation. Comput Aided Surg 1999;4:65-76. 
47.Zheng G, Zhang X, Haschtmann D, Gédet P, Langlotz F, Nolte LP. Accurate and reliable pose recovery of distal locking holes in computer-assisted intra-medullary nailing of femoral shaft fractures: a preliminary study. Comput Aided Surg 2007; 12:138-51

48. Krettek C, Mannss J, Miclau T, Schandelmaier P, Linnemann I, Tscherne H. Deformation of femoral nails with intramedullary insertion. J Orthop Res 1998;16:572-5.
49. Suhm N, Jacob AL, Nolte LP, Regazzoni P, Messmer P. Surgical navigation based on fluoroscopy--clinical application for computer-assisted distal locking of intramedullary implants. Comput Aided Surg 2000;5:391-400.

50. Suhm N, Messmer P, Zuna I, Jacob LA, Regazzoni P. Fluoroscopic guidance versus surgical navigation for distal locking of intramedullary implants. A prospective, controlled clinical study. Injury 2004;35:567-74. 